\title{
Uterine Involution in Finnish Dairy Cows
}

\author{
By P. V. A. Miettinen
}

Department of Anatomy, University of Kuopio, Finland.

\begin{abstract}
Miettinen, P. V. A.: Uterine involution in Finnish dairy cows. Acta vet. scand. 1990, 31, 181-185. - The effect of parity on the cervical and uterine involution was studied in 79 Finnish dairy cows on a research farm. The cows were examined clinically by rectal palpation 3 times a week during 8 weeks postpartum. The diameters of the cervix and uterine horns were estimated manually. The parous uterine horn was compared with the non-parous one. The results were separately analysed in primiparous cows $(n=18)$ and in those with the third calving $(n=61)$. A significant difference $(p<0.001)$ between the parous and non-parous uterine horns was obtained until 21 days. Thereafter, involution still continued and equal diameters for the horns were not found until 5 weeks after parturition. A decline of the cervical diameter continued until 30 days after the delivery. The parity had no significant effect on the swiftness of uterine or cervical involution. However, in multiparous cows the cervical diameter remained larger than that in the primiparous animals still at 8 weeks postpartum.
\end{abstract}

parity; puerperium; rectal palpation.

\section{Introduction}

The recovery of the uterus from the pregnant state after parturition is called uterine involution. Within 3-7 weeks the uterus has returned to its pregravid size. The wide range reported for the completion of the involution process may be due to variation in the criteria utilized (Malven 1984). Drastic reduction in size and reorganization of tissue is necessary before another pregnancy can be initiated. These changes include 3 overlapping processes: (1) reduction in size, (2) loss of tissue and (3) tissue repair. Early reduction in uterine size, which is partially due to peristaltic contractions of smooth muscle, progresses in a decreasing logarithmic scale with the major change occurring during the first few days after parturition (Gier \& Marion 1968). Prostaglandin $F_{2 a}$, measured as metabolites, with the ability to contract smooth muscle cells and consequently to increase the uterine tone are released for 7-23 days postpartum (Lindell et al. 1982). Postpartum uteri contracted to a half of the gravid diameter at about 5 days and to a half of the gravid length at 15 days and the weight of the uterus decreases from $9 \mathrm{~kg}$ at parturition to $1.0 \mathrm{~kg}$ at 30 days and to $0.75 \mathrm{~kg}$ at 50 days postpartum (Gier \& Marion 1968). The involution of the placenta takes place through vasoconstriction, dissolution of the decidua and formation of the uterine lochia (Rasbech 1950). The caruncular stalk generally disappears within 9 days postpartum. The normal lochial discharge consist of various cell forms (Vandeplassche 1981) and the amount of uterine lochia is largest in the first two days, making about $1500 \mathrm{ml}$ and decreases within 2 weeks to a few $\mathrm{ml}$ (Rasbech 1950). The caruncular surface is covered by a new epithelium at 25 days after parturition (Gier \& Marion 1968). The shrinkage of the vascular system and muscular contractions continue to reduce the size of the postgravid uterus until it reaches a near pregravid size by 40 to 50 
days after parturition (Gier \& Marion 1968). Histologically the involution has been found completed at 6 weeks (Schulz \& Grunert 1959).

The delayed uterine involution often interferes with the rebreeding of the cow. Obviously many factors may influence the involution process including the cattle breed (Marion et al. 1968, Fonseca et al. 1983, Larsson et al. 1984) and parity (Rasbech 1950, Marion et al. 1968, Fonseca et al. 1983, Larsson et al. 1984). Heinonen et al. (1988) found no differences in the uterine or cervical involution between the Finnish breeds of Ayrshire and Friesian cows. However, the involution time seemed to decrease with increasing parity.

The purpose of the present study was to evaluate the influence of parity on the uterine and cervical involution in the Finnish dairy cows to find out suitable criteria for the course of normal involution.

\section{Materials and methods \\ Animals}

In this study a total of 79 cows were included; 18 of them were primiparous cattle and the remaining 61 cows were calving for the third time. Both groups of animals consisted of the Finnish Ayrshire $(n=32)$, Friesian breeds $(n=35)$ and Finncattle $(n=12)$. The calving season was from April to August. Cows with gestation periods less than 260 days were regarded as abnormal and were therefore excluded from the study. The difficulties of calving and veterinary treatments were registered. All animals included had a normal and easy calving (unassisted or assisted by 1 person) and they had no clinically detectable disturbancies of the genital tract during the postpartum period.

\section{Management}

The cows were fed according to the Finnish standards. They were housed indoors on a research farm throughout the study but allowed to stay outdoors in a paddock once a weeks for $1 \mathrm{~h}$. They were milked twice daily at 7 to 9 a. m. and at 4 to 6 p. m. External signs of heat were checked 3 times daily by the herdsmen.

\section{Methods}

The cows were examined clinically 3 times a week between calving and the first insemination, which normally took place at the first heat by 8 weeks after the previous delivery. The examination included inspection of the vulva and perineum as well as rectal palpation of the cervix, uterine horns and ovaries. The diameters of cervix and both uterine horns at the external bifurcation were estimated by palpation and reported in centimeter. One examiner carried out all studies, but previous findings were not available during the subsequent examination.

The uterine involution was considered complete, when both horns were nearly symmetrical and there was no further change between 2 consecutive examinations. For each animal the time was recorded when the uterus was within or at the edge of the pelvic cavity, i.e. in the pelvic cavity position (P.C.P.). The end of the cervical involution was the time required for the mid-cervix diameter to reach the nadir.

The means ( \pm S.D.) of the measurements were calculated for readings obtained at 3, 4, 5 and 8 weeks after parturition. Student's t-test was used in the statistical comparison of the results.

\section{Results}

\section{Uterine involution}

The time required for the uterus to reach the P.C.P. position was $16.4 \pm 2.5$ and $15.7 \pm$ 2,3 days for primiparous and multiparous cows, while complete uterine involution for 
these groups was obtained at $24.7 \pm 3.6$ and $25.7 \pm 4.0$ days, respectively.

At 3 weeks postpartum the diameter of the parous uterine horn was $3.7 \pm 0.7 \mathrm{~cm}$ and the corresponding value for the cows of the third calving was $3.8 \pm 0.7 \mathrm{~cm}$. They did not differ from each other but were highly significantly ( $p<0.001$ ) different from the diameter of the non-parous control horn. In both groups the mean diameter decreased at the same rate (Fig. $1 \mathrm{a}, \mathrm{b}$ ). A significant ( $\mathrm{p}<$ 0.05 ) difference between the parous and non-parous horn was still present at 4 weeks in both groups, while at 5 weeks the values did not differ any more from each other.
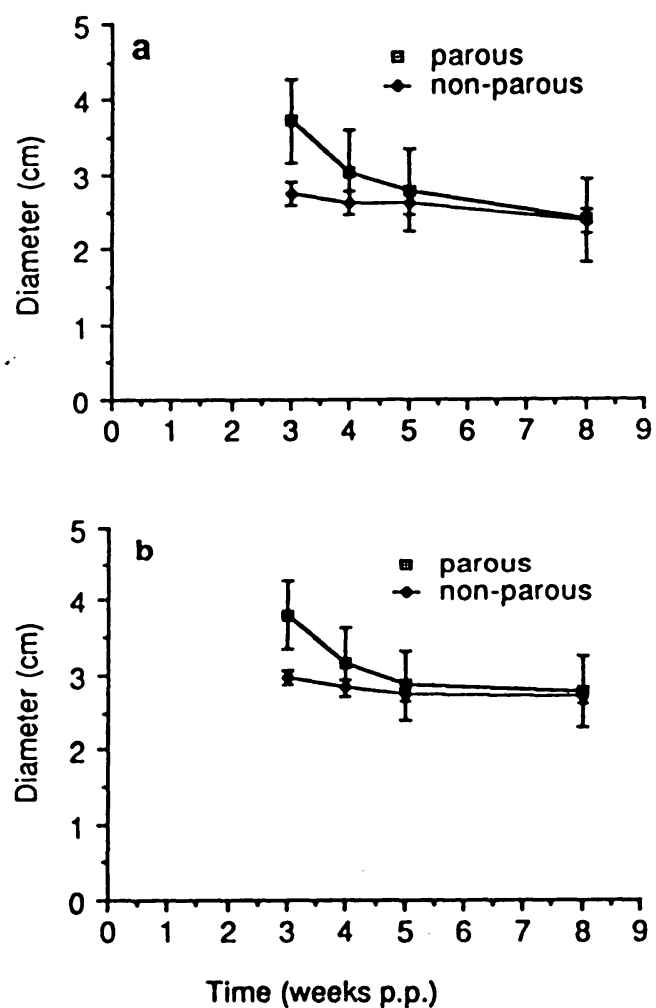

Figure 1. Involution of uterine horns in a) primiparous and b) multiparous cows. Diameter of parous and non-parous horns in $\mathrm{cm}$ obtained at 3,4, 5 and 8 weeks postpartum.

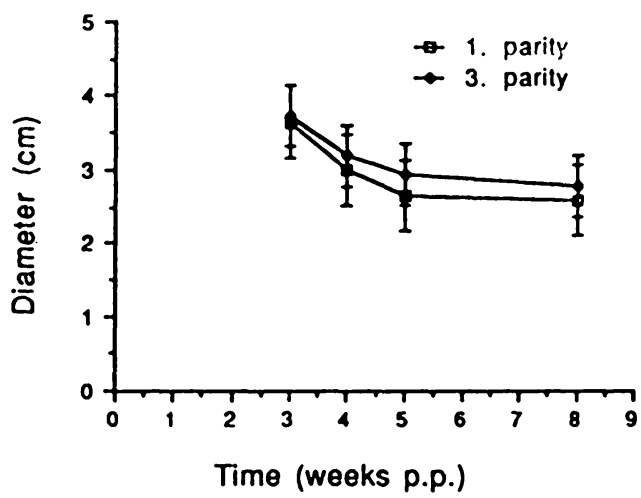

Figure 2. Involution of cervix. Diameter of cervix in cm obtained at 3, 4, 5 and 8 weeks postpartum in primiparous (1. parity) and multiparous ( 3 . parity) cows.

The involution of the cervix was complete at $30.1 \pm 3.8$ days for primiparous cows and at $30.0 \pm 4.3$ days for those calving for the third time. The cervix diameter in the 2 groups was quite similar still at 3 weeks after parturition, i.e., $3.6 \pm 0.5 \mathrm{~cm}$ and $3.7 \pm 0.4$ $\mathrm{cm}$ for the primiparous and multiparous groups, respectively. Thereafter the cervix involution in the multiparous cows was slower and a significant $(p<0.05)$ difference between the groups was found beyond 4 weeks postpartum (Fig. 2).

The interval from parturition to first service was $73.6 \pm 13.6$ days in primiparous and $72.9 \pm 9.7$ days in multiparous cows and the intervals from parturition to conception were $86.2 \pm 25.5$ and $80.8 \pm 20.2$ days, respectively.

No significant differences were encountered in any values obtained for the Finnish breeds of Ayrshire and Friesian cows. However, the intervals from calving to pregnancy were $76.4 \pm 17.5$ and $87.6 \pm 23.2$ days $(p$ $<0.06$ ), respectively, for these 2 breeds in the third lactation. 


\section{Discussion}

The purpose of the present study was to evaluate the influence of parity on uterine and cervical involution in Finnish dairy cows. The diameter of cervix and uterine horns were estimated by rectal examination rather than measured. However, all comparisons were made among animals treated identically and the data were collected by the same examiner.

The uteri of the primiparous cows followed the same involution pattern as those of the multiparous ones. The reduction in the uterine size proceeded rapidly with the greatest change occurring during the first few days. This is in agreement with the findings of Morrow et al. (1966), Gier \& Marion (1968), Marion et al. (1968), and Bostedt et al. (1976), who have reported the major regression taking place during the first 15 days. The initial involution is closely related to the release of $\mathrm{PGF}_{2 \mathrm{a}}$ (Lindell et al. 1982), which increases uterine tone. The involution is delayed in cows with postpartum diseases such as milk fever, dystocia and retained fetal membranes (Morrow et al. 1966) and in cows with abnormal discharge (Oltenacu et al. 1983).

The interval from calving to the complete uterine involution was somewhat longer than reported in the study of Rasbech (1950) and Fonseca et al. (1983) and shorter than found by Marion \& Gier (1968), Moller (1970) and Larsson et al. (1984). This discrepancy may be the result of a different definition of involution and of the intervals of clinical examination. The parity did not seem to affect the involution of the genital tract. This finding is similar to that described by Moller (1970). Many authors have suggested that the involution is faster in the younger cows than in the old ones (Rasbech 1950, Morrow et al. 1966, Marion et al. 1968, Oltenacu et al. 1983, Larsson et al. 1984). Malven (1984) suggested that the retardation in uterine involution with advancing parity is due to uterine trauma associated with successive parturitions.

Breed differencies are found in uterine involution (Marion et al. 1968, Fonseca et al. 1983, Larsson et al. 1983), but in this study there was no differences between Finnish Ayrshire and Friesian breed and it seemed to be the same for Finncattle, too. There are large differences between breeds in calving performance (Berglund \& Philipsson 1987). The cows in the present work had no difficulties in calving. That can be one explanation for an identical rate of uterine involution in the Finnish dairy cows. However, contrary to the report of Heinonen et al. (1988) the interval from calving to the complete uterine involution did not decrease with parity. Nevertheless, an identical clinical estimation of symmetry or asymmetry of the uterine horns has been used in both these studies. Thus, at 4 weeks postpartum the difference between parous and nonparous horns was palpable but at 5 weeks no difference could be discerned any more. This corroborates the observations of Morrow et al. (1966) and Gier \& Marion (1968). In conclusion, the results of this study indicate that the parity has no significant effect on the swiftness of uterine or cervical involution in the Finnish dairy cows. In multiparous cows the cervix, however, remains thicker for a longer time than in the primiparous animals. No significant differences were observed in the uterine and cervical involution of the 3 Finnish cattle breeds studied.

\section{References}

Berglund B, Philipsson J: The influence of relative birth weight and certain other factors on calving performance in Swedish dairy cattle breeds. Anim. Reprod. Sci. 1987, 15, 81-93. 
Bostedt $H$, Reissinger $H$, Günzler $D$ : Klinische Erhebungen über den Verlauf bei Rindern aus Beständen mit Fertilitätsproblemen. (Clinical findings on the course of the puerperal period in cows on farms with fertility problems). Berl. Münch. Tierärtzl. Wschr. 1976, 89, 24 28.

Fonseca FA, Britt JH, McDaniel BT, Wilk JC, Rakes $A H$ : Reproductive traits of Holsteins and Jerseys. Effects of age, milk yield, and clinical abnormalities on involution of cervix and uterus, ovilation, estrous cycles, detection of estrus, conception rate, and days open. J. Dairy Sci. 1983, 66, 1128-1147.

Gier HT, Marion GB: Uterus of the cow after parturition: Involutional changes. Amer. J. vet. Res. 1968, 29, 83-96.

Heinonen K, Miettinen P, Savolainen E, Tuovinen $V$, Alanko $M$ : Postpartum reproductive function in Finnish Ayrshire and Friesian cows after three subsequent parturitions. Acta vet. scand. 1988, 29, 231-238.

Larsson $K$, Jansson L, Berglund B, Edqvist L-E, Kindahl $H$ : Postpartum reproductive performance in dairy cows. Acta vet. scand. 1984, $25,445-461$.

Lindell $J-O$, Kindahl $H$, Jansson $L$, Endqvist $L-E$ : Post-partum release of prostaglandin $\mathrm{F}_{2 \mathrm{a}}$ and uterine involution in the cow. Theriogenology 1982, 17, 237-245.

Malven PV: Pathophysiology of the puerperium: definition of the problem. Proc. 10th Int. Congr. Anim. repr. and A.I., Illinois 1984, IV, III-1-8.

Marion GB, Norwood JS, Gier HT: Uterus of the cow after parturition: Factors affecting regression. Amer. J. vet. Res. 1968, 29, 71-75.

Moller $K$ : Uterine involution and ovarian activity after calving. N.Z. vet. J. 1970, 18, 140-145.
Morrow DA, Roberts SJ, McEntee K, Gray HG: Postpartum ovarian activity and uterine involution in dairy cattle. J. Amer. vet. med. Assoc. 1966, 149, 1596-1609.

Oltenacu PA, Britt JH, Braun RK, Mellenberger $R W$ : Relationship among type of parturition, type of discharge from genital tract, involution of cervix, and subsequent reproductive performance in Holstein cows. J. Dairy Sci. 1983, 66, 612-619.

Rasbech NO: Den normale involutio uteri hos koen. (The normal involution of the uterus in the cow). Nord. Vet.-Med. 1950, 2, 655-687.

Schulz LCI, Grunert E: Physiologie und Pathologie der puerperalen Involution des Rinderuterus. (Physiology and pathology of involution of the puerperal uterus in cattle). Dtsch. Tierärztl. Wochensch. 1959, 66, 29-37.

Wandeplassche $M$ : Neue vergleichende Aspekte der Involution und der puerperalen Metritis bei Stute, Kuh und Sau. (New comparative aspects of involution and puerperal metritis in mare, cow, and sow). Mh. Vet.-Med. 1981, $36,804-807$.

\section{Sammanfattning \\ Livmoderns involution hos finska mjölkkor.}

Ändamålet med föreliggande undersökningen var att studera inverkan av antalet kalvningar på livmoderinvolution hos finska mjölkkor.

18 primipara och 61 multipara kor undersöktes på en försöksgård. Korna undersöktes kliniskt genom rektalpalpation 3 gånger per vecka under 8 veckor postpartum. Tiden från kalving til fullständig involution av livmoder och cervix registrerades.

Intervallen mellan kalvningen och den avslutade livmoderinvolutionen påverkades inte av hur många gånger korna hade kalvat.

(Accepted September 11, 1989).

Reprints may be requested from: P. Miettinen, Department of Anatomy, University of Kuopio, P. O. Box 6, SF-70211 Kuopio, Finland. 